\title{
"Economic and legal mechanisms for effective use of land resources under the conditions of sustainable development in Ukraine"
}

\begin{tabular}{|c|c|}
\hline \multirow{5}{*}{ AUTHORS } & \multirow{2}{*}{$\begin{array}{l}\text { Ivan Kostyashkin } \\
\text { Bogdan Derevyanko (D https://orcid.org/0000-0001-7408-8285 }\end{array}$} \\
\hline & \\
\hline & R https://publons.com/researcher/2454637/bogdan-derevyanko/ \\
\hline & Vasyl Hrudnytskyi (D https://orcid.org/0000-0003-3161-4147 \\
\hline & Tetiana Shlapko (D https://orcid.org/0000-0003-1619-3831 \\
\hline ARTICLE INFO & $\begin{array}{l}\text { Ivan Kostyashkin, Bogdan Derevyanko, Vasyl Hrudnytskyi and Tetiana Shlapko } \\
\text { (2018). Economic and legal mechanisms for effective use of land resources } \\
\text { under the conditions of sustainable development in Ukraine. Environmental } \\
\text { Economics, } 9(3), 42-50 \text {. doi:10.21511/ee.09(3).2018.05 }\end{array}$ \\
\hline DOI & http://dx.doi.org/10.21511/ee.09(3).2018.05 \\
\hline RELEASED ON & Wednesday, 31 October 2018 \\
\hline RECEIVED ON & Thursday, 10 May 2018 \\
\hline ACCEPTED ON & Tuesday, 30 October 2018 \\
\hline & $(\mathrm{coc}) \mathrm{EY}$ \\
\hline LICENSE & $\begin{array}{l}\text { This work is licensed under a Creative Commons Attribution } 4.0 \text { International } \\
\text { License }\end{array}$ \\
\hline JOURNAL & "Environmental Economics" \\
\hline ISSN PRINT & $1998-6041$ \\
\hline ISSN ONLINE & $1998-605 X$ \\
\hline PUBLISHER & LLC "Consulting Publishing Company "Business Perspectives" \\
\hline FOUNDER & LLC "Consulting Publishing Company "Business Perspectives" \\
\hline$\sigma^{0}$ & 三ニ: \\
\hline NUMBER OF REFERENCES & NUMBER OF FIGURES \\
\hline 29 & 2 \\
\hline
\end{tabular}

(c) The author(s) 2022. This publication is an open access article. 


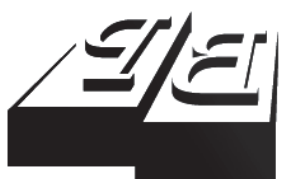

BUSINESS PERSPECTIVES

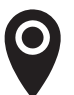

LLC "CPC "Business Perspectives" Hryhorii Skovoroda lane, 10, Sumy, 40022, Ukraine

www.businessperspectives.org

Received on: $10^{\text {th }}$ of May, 2018 Accepted on: $30^{\text {th }}$ of October, 2018

C Ivan Kostyashkin, Bogdan Derevyanko, Vasyl Hrudnytskyi, Tetiana Shlapko, 2018

Ivan Kostyashkin, Doctor of Law, Associate Professor, Khmelnytsky University of Management and Law, Ukraine.

Bogdan Derevyanko, Doctor of Law, Professor, Donetsk Law Institute of the Ministry of Internal Affairs of Ukraine, Ukraine.

Vasyl Hrudnytskyi, Ph.D. (Law), Associate Professor, State Institution of Higher Education "Donetsk National Technical University", Ukraine.

Tetiana Shlapko, Ph.D. (Law), Associate Professor, Sumy State University, Educational and Research Institute of Law, Ukraine.

\section{(ㄷ)(ㄱ)}

This is an Open Access article, distributed under the terms of the Creative Commons Attribution 4.0 International license, which permits unrestricted re-use, distribution, and reproduction in any medium, provided the original work is properly cited.
Ivan Kostyashkin (Ukraine), Bogdan Derevyanko (Ukraine), Vasyl Hrudnytskyi (Ukraine), Tetiana Shlapko (Ukraine)

\section{ECONOMIC AND LEGAL} MECHANISMS FOR EFFECTIVE USE OF LAND RESOURCES UNDER THE CONDITIONS OF SUSTAINABLE
DEVELOPMENT IN UKRAINE

\begin{abstract}
Sustainable society development distinctly entails the issues of sustainable use of land and especially soils, which are the place and condition of human activity, the means of production that provide absolute value, and a unique natural resource. Ukraine possesses nine percent of the world's black soil (chernozem) resources, which necessitates the development of sufficient economic and legal mechanisms for their effective use in ensuring food security within the country and worldwide, increasing the export potential of Ukraine subject to the soil quality restoration, and determines the scope of this work. The land reform in Ukraine as a component of economic reform has led to a significant deterioration of agricultural land, loss of humus from soils, their degradation, and other negative consequences threatening the country's economic security and generating socio-economic and demographic crisis phenomena, especially in rural areas. Therefore, the study has identified priorities and has proposed the use of contractual mechanisms in the field of sustainable socio-economic use of land resources.
\end{abstract}

The authors applied an integrated approach to the analysis of sustainable land use issues to achieve the study objective. This led to the use of a wide range of methodological tools, in particular, the dialectical method, the formal logical method, the logical legal method and the methods of analysis, synthesis and comparison.

Defined provisions that determine the economic and legal mechanism of land use and should be ensured in the process of sustainable development: meeting the needs of landowners and other persons, including the priority needs - environmental and food security; an increase in the area of land not involved in the economic turnover, the adoption of measures aimed at the preservation and restoration of agricultural land, in particular compliance with the requirements for crop rotation, and, in some cases, their conservation; introduction of contractual relations in the field of land use.

\section{Keywords}

\section{JEL Classification} sustainable development, efficient land use, lan ownership, contractual land use, land reform

\section{INTRODUCTION}

The land acts as a place of human activity and is a unique source of energy, because it produces a biological mass under the action of the sun and then generates biological energy, which is a necessary condition for life, which, certainly, determines the characteristics of land ownership. The role and importance of land in the formation of absolute and surplus value should be taken as the basis for developing the economic and legal mechanism for regulating land relations, which will be a key to the state's food and economic security and a guarantee of both its economic sovereignty and the leading position in world markets. Shulha notes that agricultural land, being a general condition and subject of agricultural labor, as well as the basic and irreplaceable means of agricultural production, is the basis of the national food se- 
curity. It is a unique natural resource, the foundation of the economic development of the state and the material well-being of the Ukrainian people (Shulha, 2015).

At the same time, in the context of a deepening global environmental crisis, the efficiency of economic activity as a whole and especially with respect to the land is being increasingly discussed in terms of environmental and social consequences. Humanity is becoming increasingly aware of the need to rethink the entire philosophy of relationships between the society and the biosphere in the process of using land resources, in general, and agricultural land, in particular, because the level of anthropogenic load should be measured and compared with the potential of the soil for self-regeneration at the current stage of agricultural land use development (Medvedyev, 2007, p. 54).

The basic principles in this area were shaped by the 1992 Rio de Janeiro Conference on Environment and Development, which adopted the Rio Declaration on Environment and Development. The Declaration enshrines a new understanding of the use of natural resources, which is not limited to simple consumption, but is subject to the protective content of the relevant legal relations, i.e., meeting the needs of citizens should not harm the environment and should not lead to depletion of natural resources (Rio Declaration on Environment and Development, 1992). The conference adopted the Agenda 21 dated June 14, 1992, which lays down the basic principles of sustainable development in the economic and social spheres, and in the sphere of conservation and rational use of natural resources.

Particular attention in the area of ensuring sustainable development at the present stage should be paid to the Association Agreement between Ukraine, of the one part, and the European Union, the European Atomic Energy Community and their Member States, of the other part, dated June 27, 2014, which has been ratified in Ukraine under the Law of Ukraine No. 1678-VII dated September 16, 2014 (The Law of Ukraine "On Ratification of the Association Agreement between Ukraine, of the one part, and the European Union, the European Atomic Energy Community and their Member States, of the other part", 2014), which provides for cooperation to promote the development of agriculture and rural areas, in particular, by promoting modern and sustainable agricultural production, taking into account the need to protect the environment and animals, the spread of organic production and the use of biotechnology, inter alia, by introducing best practices in these areas, promoting agricultural quality policy in the area of product standards, production requirements and quality schemes.

The corresponding situation requires a new understanding of the content and role of land ownership, guarantees a stable growth of the state, increasing the well-being of citizens and overcoming negative environmental and social phenomena. Current issues in the formation of the economic and legal mechanism of land ownership require a theoretical analysis of the combination of public and private interests in the use of land as the main national wealth by ensuring the economic, environmental and social components of land ownership.

\section{LITERATURE REVIEW}

Economic and environmental interests should ensure the quality of life of the population. Vasylyeva notes that environmental interests cannot be secured apart from economic ones. Protecting public environmental interest is simply impossible in an "autonomous mode", outside the sphere of industrial relations. Therefore, future policy-making must always take into account the real economic and legal framework, in which the public environmental interest exists, and, primarily, take into account the objective laws and requirements of economic development (Vasylyeva, 1999, p. 51). A certain balance of environmental interests and economic needs in this case is undoubtedly provided by the concept of sustainable socio-economic development, which provides for certain restrictions on the exploitation of natural resources, but these restrictions are not absolute, they are relative and are related, according to Brynchuk, to the current level of 
technology and social organization, as well as the ability of the biosphere to cope with the consequences of human activity (Brynchuk, 2010).

Nosik (2011) believes that the prospect of development of land relations should be based on the methodological and doctrinal foundations of the functional land use for progressive economic development. In fact, the land with its fertile layer is the main wealth of the nation and the people, which determines the public nature of the property. Further, Nosik (2011) emphasizes the special role of the right to private land ownership, which is the economic and legal basis of freedom and guarantees the private interests of a person. The scientist identifies the methodological framework for the implementation of property rights, including free economic activity, independent production of capital and its free distribution, the combination of the landowner and the farmer in one person, the absence of other taxes, except for land rent in its monetary terms. Such approaches form the foundation for a combination of public and private interests in land ownership relations and thus guarantee the provision of important social and economic functions for the preservation and use of land by private owners for the purpose of progressive social development (Nosik, 2011, pp. 103-104).

The results of the paper of Miceli, Sirmans, and Turnbull (1998) suggest that in most cases, land registration is preferred to the recording system on exchange and investment grounds, holding other factors constant. Lambin and Meyfroidt (2011) concluded that globalization can be harnessed to increase land use efficiency rather than leading to uncontrolled land use expansion. To do so, land systems should be understood and modeled as open systems with large flows of goods, people, and capital that connect local land use with global-scale factors.

Sklenicka et al.'s (2014) study demonstrates a phenomenon that we call the Farmland Rental Paradox, where very small parcels tend to create large production blocks by being rented to larger farmers, and therefore to significantly homogenize the land use pattern. The parcel size established as the threshold for this phenomenon is 1.07 ha. Below this threshold, the smaller the parcels were, the larger the blocks that they tended to create. Using the example of the Czech Republic, a state with extremely high farmland ownership fragmentation, it is demonstrated that this phenomenon can currently determine the land use of up to $40 \%$ of the country's farmland. Our study also points to other countries where this phenomenon may apply, especially the transitional countries of Central and Eastern Europe (Sklenicka, Janovska, Salek, Vlasak, \& Molnarova, 2014). Sklenicka review of relevant literature enables the further presentation of a list of 21 types of land degradation and another extensive list of the 37 most common causes of land degradation. His work further presents an overview of harmful consequences of high farmland ownership fragmentation, and possibilities for remedying the effects. These possibilities consist of eliminating or mitigating those causes accelerating the fragmentation process, defragmenting current land ownership, and remedying the effects brought by this process (Sklenicka, 2016). Irwin and Bockstael (2002) develop a model of land use conversion that incorporates local spillover effects among spatially distributed agents. The model is used to test the hypothesis that fragmented patterns of development in rural-urban fringe areas could be due to negative externalities that create a 'repelling' effect among residential land parcels (Irwin \& Bockstael, 2002).

\section{METHODS}

Two groups of scientific cognition methods were used to prepare this scientific article - general scientific methods (dialectical, systemic, logical analysis and synthesis methods, formal logical, structural and functional, and complex analysis), as well as special legal research methods (comparative legal, concretization and interpretation of legal rules, formal legal, historical legal).

In general, a combination of the dialectic method, the formal logical method, the logical legal method and the methods of analysis, synthesis and comparison was used. These methods were used to identify certain problems in the agrarian sector of the economy; to determine the capabilities of the state, individual landowners 
and land users to ensure the sustainable use of land resources on a contractual basis. The analogy and comparison were used to determine the state of land resources and agricultural production in Ukraine and the European Union countries.

\section{RESEARCH RESULTS}

Rudenko (1998), the developer of the progress energy theory, sharing the views of François Quesnay, the founder of the physiocrats' economic theories, derived the added value from nature itself, i.e., the ability of the land to yield a harvest and thus increase the wealth of the nation and state. Quesnay's followers considered the growth of organic matter in agriculture to be an absolute wealth (Rudenko, 1998, p. 486). The use of any energy sources accumulated on the earth leads to complete exhaustion. It is especially evident in the last years of scientific and technological progress. Only the farming, subject to the respect for the land and compliance with elementary technological requirements, in particular, crop rotations, fertilization of soil, soil quality standards, etc., is capable of both constant reproduction and increasing the yield of agricultural products year in year out.

Describing the process of production of material goods due to soil fertility, Rudenko pays special attention to market mechanisms of land management. Nature, according to the scientist, can give eternal life only to an economic system, in which people do not work forcibly but are guided by their hearts. Only the freedom produces wealth! Where the producer is not a master of the fruits of its labor - no matter how this formation is called - the economic system must collapse (Rudenko, 1998, p. 404). It is quite appropriate to recall Aristotle's famous statement that "property is the foundation of freedom". The owner who works on the land can provide a combination of economic effect and positive environmental effects, including soil quality and environmental safety. Given market competition, only the qualitative soil will allow an agricultural producer to expect a sufficient harvest and competitiveness of its products. At the same time, a binding to a specific land plot obliges the producer to invest in improving soil handling, crop rotation, improving the soil quality, thus ensuring a profitable business.

In particular, the main principles of the European Union's policy on land ownership, including agricultural lands, are ensuring the right to free movement of capital, opening and running a private business and non-discrimination. Most European Union countries do not impose legal restrictions on the ownership of agricultural land (any individual or legal entity can legally acquire and own an agricultural land plot). Separate legal restrictions on the ownership of agricultural land may only limit the number of potential buyers and competition on the part of the agricultural land market (Resolution of the Cabinet of Ministers of Ukraine "Strategy for Improving the Management Mechanism in the Use and Protection of StateOwned Agricultural Lands", 2017).

Instead, by proclaiming the redistribution of land with its simultaneous transfer to private and collective ownership to be the task of land reform in Ukraine, the state actually ensured the development of rental land use. After twenty-seven years of land reform, the landowners were put aside from land handling, and super-powered rental agricultural enterprises, which activities are generally aimed at obtaining super-profits, leaving environmental and social issues outside their field of interest, entered the market. Describing the owners of such enterprises, some authors, for example, Maliyenko (2011) notes that, unlike the landowners of past eras, they do not have estates in the villages and do not live there even temporarily. They are not interested in the work of the peasants, the social and cultural development of the village, the favorable ecology of the agrarian territories. They perceive the land as a production resource or an object of speculation, and regard the village and its inhabitants as an extra element, which presence in the territory increases the cost of protecting crops and material values (Maliyenko, 2011, p. 8).

The land potential concentrated in Ukraine significantly exceeds the European indicators for the area of black soil, defining the agricultural prospects of Ukraine, both for its own needs and for the needs of the European Union, taking into account the export data of agricultural products, which is shown in Table 1. 
Table 1. Comparative characteristics of land use in European countries and Ukraine

Source: Resolution of the Cabinet of Ministers of Ukraine "Strategy for Improving the Management Mechanism in the Use and Protection of StateOwned Agricultural Lands" (2017).

\begin{tabular}{|c|c|c|}
\hline Indicator & Ukraine & $\begin{array}{l}\text { The European } \\
\text { Union countries }\end{array}$ \\
\hline $\begin{array}{l}\text { Land area, } \\
\text { million hectares }\end{array}$ & 60,4 & 437,4 \\
\hline $\begin{array}{l}\text { Black soil area, } \\
\text { million hectares }\end{array}$ & 28 & 18 \\
\hline $\begin{array}{l}\text { Leased agricultural land, } \\
\text { percentage }\end{array}$ & 97 & 53 \\
\hline $\begin{array}{l}\text { Grain exports, } \\
\text { million tons }\end{array}$ & 34,8 & 38,5 \\
\hline
\end{tabular}

At the same time, while working on his research under the conditions of a state-run economy, Rudenko somewhat absolutized the market and considered the state, which assumes the functions of an intermediary in marketing the crops (thus destroying agriculture and depleting soils), the greatest threat to an agricultural producer. We agree with this approach, in general, but should note that under modern conditions the state has the obligation to harmonize and balance public and private interests, including in land ownership relations, since the assertion and maintenance of human rights and freedoms is the primary obligation of the state, and land is the main national wealth. The state should perform controlling and stimulating functions both at the stage of obtaining of agricultural products and during their marketing through the announcement of tenders for the purchase of such products and the provision of subsidies to agricultural producers, as it is done in the European Union. Unfortunately, the negative experience of Latin American countries and the development of large-scale rental agricultural production in Ukraine shows that individual enterprises, not being landowners, do not fulfill their social function in soil protection and production of high-quality agricultural products in pursuit of super-profits. (The Law of Ukraine "On the Main Principles (Strategy) of the State Environmental Policy of Ukraine for the period up to 2020", 2010). Therefore, the state should exercise control to ensure the rational use of agricultural land, reproduce soil quality, observe crop rotation (Land Code of Ukraine, 2001; The Law of Ukraine "On Land Protection", 2003), prevent the development of latifundia, etc.
Land use under any conditions should provide for a certain positive effect. At present, the efficiency of agriculture in Ukraine in terms of per capita production is much lower than in advanced European countries.

\section{Table 2. Agricultural land use efficiency}

Source: Resolution of the Cabinet of Ministers of Ukraine "Strategy for Improving the Management Mechanism in the Use and Protection of StateOwned Agricultural Lands" (2017)

\begin{tabular}{|c|c|c|}
\hline Country & $\begin{array}{l}\text { The agricultural area } \\
\text { per capita engaged } \\
\text { in agricultural } \\
\text { production, hectares }\end{array}$ & $\begin{array}{c}\text { Production volume } \\
\text { per capita engaged } \\
\text { in agricultural } \\
\text { production, } \\
\text { thousand euros }\end{array}$ \\
\hline Ukraine & 24 & 4 \\
\hline Latvia & 13 & 6 \\
\hline Lithuania & 13 & 8 \\
\hline Poland & 7 & 8 \\
\hline Hungary & 26 & 16 \\
\hline Estonia & 44 & 19 \\
\hline Bulgaria & 22 & 19 \\
\hline Slovenia & 20 & 21 \\
\hline Greece & 46 & 23 \\
\hline $\begin{array}{l}\text { Czech } \\
\text { Republic }\end{array}$ & 23 & 30 \\
\hline Italy & 27 & 42 \\
\hline Austria & 20 & 44 \\
\hline Sweden & 42 & 80 \\
\hline Germany & 13 & 83 \\
\hline France & 35 & 90 \\
\hline
\end{tabular}

The effective land use can be interpreted in different ways: ranging from the receipt of higher profits to the priority protection of lands in the process of their use. However, both the first and the second variants imply the final adoption of measures to maintain and restore the quality of land, since only under such conditions, agricultural producers can a high profitability over a long period, and at the same time, such measures will ensure its protection. Thus, it is indisputable that the most efficient land use will be when achieving maximum benefit occurs under the condition of preventing the deterioration of both the lands themselves and the natural objects located on them, and taking measures to improve soil properties when it comes to agricultural production. Therefore, productive and efficient land use, which is aimed at satisfying the material, spiritual and other life-supporting needs of a person and citizen, nation, state, economic entities, occurs subject to the indispensable implementation of a set of measures aimed at restoring and improving soil fertility (Andreytsev, 2005, p. 46). 
The methodology of such land use should ensure the avoidance of both economic (maximum increase in productivity and profitability of land) and environmental (restoration of agricultural landscapes by the parameters of natural systems) "extremism" (Ohinskyi, 2000, p. 61). In other words, the concept of sustainable development involves the formation of a management system, which is based on the principles of a balanced combination of economic and environmental criteria for its development (Kulynych, 2011, p. 90).

The law establishes both certain parameters of the freedom of economic use of land and economically necessary disposal of land to create conditions for obtaining and increasing profits for business entities. Legal regulation restricts an agricultural entrepreneur in obtaining profits through the use of land by methods that lead to the deterioration of its natural properties (Ikonitskaya \& Krasnov, 1998 , p. 113). Instead, the deterioration of natural properties of land, in turn, will lead to a decrease in returns, and, consequently, low profitability of lands. Thus, by such actions, the legislator both ensures the preservation of land and guarantees stability in profit making by those entrepreneurs, whose activity restrictions are established by the relevant legal rules.

However, the overwhelming majority of agricultural producers do not comply with modern protective technologies for land handling, do not ensure the adoption of necessary measures to conserve soil and increase its fertility, which leads to a deterioration in the quality of the soil, soil degradation, and a decrease in the humus composition (Hominets \& Shulha, 2015, p. 37; Borisova, 2001; Popova, 2000). Thus, over the past 20 years, the average humus content in Ukraine has decreased by 0.22 percent in absolute terms, which is a significant deviation, since it may take 25-30 years to increase it in soil by 0.1 percent in natural conditions (Resolution of the Cabinet of Ministers of Ukraine "Strategy for Improving the Management Mechanism in the Use and Protection of StateOwned Agricultural Lands", 2017). Therefore, the set of regulations defining the obligations of citizens in the field of conservation and reproduction of land, as well as responsibility measures, such as a traditional method of land protection, should be supplemented by raising the legal, agrotechnical culture of citizens and economic entities that need to understand the exceptional socio-economic value of land, which consists, above all, in its beneficial properties as an object of nature. The condition for achieving this level of legal awareness is the introduction of contractual relations and social partnership, which should provide business entities with clear guidelines for the use of individual land plots.

The use of agricultural land should be differentiated depending on the natural conditions, soil cover, which implies the need for its localization. Nosik introduced separate proposals on local legal regulation in the field of land handling, through the "enterprise standards" to establish mandatory agrotechnical rules for individual land users (Nosik, 1986, p. 14).

At this stage of market transformations in the agricultural sector, a prerequisite for the effective provision of sustainable agricultural land use is the expansion of the scope of contractual regulation of land title. According to Danylenko (2012), the contract that is concluded by the landowner or land user with the relevant entity may reflect the peculiarities of land use, the characteristics of each land plot included in its composition. It is proposed to conclude an agreement on protection restrictions and an agreement on the development of crop farming system project (Danylenko, 2012, pp. 10-11). However, the author of such proposals does not express sufficiently substantiated positions with respect to the parties to the relevant contract, which, in his opinion, may be landowners and land users and, of the other part, authorized state or local government agencies, an environmental non-governmental organization and a consulting firm providing services in the area of agricultural production servicing. We believe that, based on the realities of the reform processes that have taken place over the past twenty-five years and their negative consequences that have affected the condition of various categories of soils and lands, such agreements, if they can exist, should be concluded with public agencies exercising certain control functions in the relevant field and exercising their authority taking into account the constitutional provisions on the land ownership of the Ukrainian people (Kostyashkin, 2016, p. 343). 
According to Kulynych (2011), the content of such contracts should include both the implementation of crop rotation standards and other established standards - standards for the optimal ratio of land, soil quality and maximum permissible soil contamination. Therefore, the public law in the field of agricultural land use is concretized in terms of the quality of agricultural land plots by clarifying the rights and obligations of their owners and users regarding the agricultural land they use in contracts, which should be concluded between the owners and users of land plots and the public agency authorized to exercise advisory, control and other organizational powers in the field of protection and use of agricultural land (Kulynych, 2011, pp. 584-585).

An important component of such contracts is the availability of incentive measures involving tax concessions or the receipt of certain state subsidies, as well as the occurrence of negative consequences in the form of certain liability measures for non-compliance with environmental protection and conservation measures.

Natural peculiarities of the land as production means provide for a special mode of use, which effectiveness directly depends on the use of natural knowledge as a condition for its preservation and restoration. This predetermines the use of the results of research of the Ukrainian Academy of Agrarian Sciences on the crop rotations in various natural and climatic zones of Ukraine un- der the modern conditions of farming, which are set out in the Methodological Recommendations on the Optimal Ratio of Agricultural Crops in the Crop Rotation of Various Soil and Climate Zones of Ukraine, approved by a joint order of the Ministry of Agrarian Policy of Ukraine and the Ukrainian Academy of Sciences No. 440/71 dated July 18, 2008 (Order of the Ministry of Agrarian Policy of Ukraine, Ministry of Finance of Ukraine "Methodological Recommendations on the Optimal Ratio of Agricultural Crops in the Crop Rotation of Various Soil and Climate Zones of Ukraine”, 2008).

Consequently, in the context of globalization of all processes occurring on the planet, relations for the implementation of land ownership take on a special character, making the owner dependent on the properties of the lands themselves and the state of the biosphere as a whole, which need constant protection and, sometimes, cessation of anthropogenic pressure. This state of affairs determines the binding nature of the implementation of land ownership, which is designed to serve the interests of both the private owner and society as a whole. Thus, society and direct owners of specific land plots are always mutually interested in preserving, restoring, protecting land and satisfying a wide variety of needs by obtaining a high yield, which involves elaborating appropriate economic and legal mechanisms capable of implementing mutual interest in environmentally sound and economically motivated land use.

\section{CONCLUSION}

Key provisions that determine the economic and legal mechanism of land use and should be ensured in the process of sustainable development include the following:

- meeting the needs of landowners and other persons, including the priority needs - environmental and food security;

- an increase in the area of land not involved in the economic turnover, the adoption of measures aimed at the preservation and restoration of agricultural land, in particular compliance with the requirements for crop rotation, and, in some cases, their conservation;

- introduction of contractual relations in the field of land use, which provides for a wide range of incentive measures and responsibility in the event of a negative impact on the state of land resources or the environment. Incentive measures may include both direct financial assistance and, above all, payment for services related, in particular, to developing the land management projects to observe crop rotation or R\&D that will provide new opportunities in effective and safe land use. 
Under such conditions, socio-economic land use in the context of sustainable development is the use of land resources when land protection is a key to high efficiency (including its profitability) in the long term. Such land use combines private and public interests in the constant and effective use of land resources while maintaining their properties, and requires further comprehensive research in economic and legal aspects. Therefore, it is necessary to announce and support future research on the current topic.

\section{REFERENCES}

1. Andreytsev, V. I. (2005). Земельне право і законодавство суверенної України: Актуальні проблеми практичної теоріі [Zemelne pravo i zakonodavstvo suverennoi Ukrainy: Aktualni problemy praktychnoi teorii] (445 p). Kyiv: Znannia. Retrieved from http://library.univer.kharkov.ua/ OpacUnicode/index.php?url=/ notices/index/IdNotice:437402/ Source:default

2. Borisova, V. A. (2001).

Економіко-екологічні засади аграрного землекористування [Ekonomiko-ekolohichni zasady ahrarnoho zemlekorystuvannia]. Ekonomika APK, 7, 16-22.

3. Brynchuk, M. M. (2010). Проблемы методологии экологического права [Problemy metodologii ekologicheskogo prava]. Retrieved from http://igpran.ru/ articles/2970

4. Danylenko, B. V. (2012). Еколого-правове забезпечення сталого сільськогосподарського землекористування [Ekolohopravove zabezpechennia staloho silskohospodarskoho zemlekorystuvannia] (Extended abstract of candidate's thesis) (20 p.).

5. Elena G. Irwin, \& Nancy E. Bockstael (2002). Interacting agents, spatial externalities and the evolution of residential land use patterns. Journal of Economic Geography, 2(1), 31-54. https://doi. org/10.1093/jeg/2.1.31

6. Eric F. Lambin, \& Patrick Meyfroidt (2011). Global land use change, economic globalization, and the looming land scarcity. PNAS, 108(9), 3465-3472. https:// doi.org/10.1073/pnas.1100480108

7. Hominets, S. V., \& Shulha, M. V. (2015). Правове забезпечення підвищення родючості грунтів [Pravove zabezpechennia pidvyshchennia rodiuchosti hruntiv] (169 p). Kharkiv: Finart.

8. Ikonitskaya, I. A., \& Krasnov, N. I. (1998). Права на землю сельскохозяйственных предпринимателей [Prava па zemlyu selskokhozyaystvennykh predprinimateley]. Proceedings from Предпринимательская деятельность в сельском хозяйстве России. Правовые вопросы [Predprinimatelskaya deyatelnost $\mathrm{v}$ selskom khozyaystve Rossii. Pravovye voprosy]. Moskow.

9. Kostyashkin, I. O. (2016). Правове забезпечення соціальної функції права власності на землю в Україні [Pravove zabezpechennia sotsialnoi funktsii prava vlasnosti na zemliu $v$ Ukraini] (429 p). Kyiv-Khmelnytskyi: Vydavnytstvo Khmelnytskoho universytetu upravlinnia ta prava.

10. Kulynych, P. F. (2011). Правові проблеми охорони і використання земель сільськогосподарського призначення в Україні [Pravovi problemy okhorony i vykorystannia zemel silskohospodarskoho pryznachennia $v$ Ukraini] (688 p). Kyiv: Lohos.

11. Supreme Council of Ukraine (2001). Land Code of Ukraine dated October 25, 2001. No. 2768III. Retrieved from http://zakon3. rada.gov.ua/laws/show/2768-14

12. Maliyenko, A. (2011). Аграрна реформа: чому так відбувається? [Ahrarna reforma: chomu tak vidbuvaietsia?]. Dzerkalo tyzhnia, Ukraina, 36, 8.

13. Medvedyev, V. V. (2007). Взаємозв'язки між антропогенними

навантаженнями, деградацією і сталістю грунтів [Vzayemozviazky mizh antropohennymy navantazhenniamy, dehradatsiieiu i stalistiu hruntiv]. Visnyk ahrarnoyi nauky, 8, 49-55.

14. Miceli, T., Sirmans, C., \& Turnbull, G. (1998). Title Assurance and Incentives for Efficient Land Use. European Journal of Law and Economics, 6(3), 305-323. https://doi. org/10.1023/A:1008614513610

15. Nosik, V. V. (1986). Правовое регулирование рационального использования земель сельскохозяйственных предприятий агропромышленного комплекса (на материалах Украинской CCP) [Pravovoe regulirovanie ratsionalnogo ispolzovaniya zemel selskokhozyaystvennykh predpriyatiy agropromyshlennogo kompleksa (na materialakh Ukrainskoy SSR)] (Extended abstract of candidate's thesis) (23 p.).

16. Nosik, V. V. (2011). Сучасні виклики та правові реаліі у регулюванні земельних $i$ аграрних відносин в Украӥні [Suchasni vyklyky ta pravovi realiyi u rehulyuvanni zemelnykh i ahrarnykh vidnosyn $v$ Ukrayini]. Proceedings from "Круглий стіл" Сучасні проблеми систематизації екологічного, земельного та аграрного законодавства України ["Kruhliy stil" Suchasni problemy systematyzatsii ekolohichnoho, zemelnoho ta ahrarnoho zakonodavstva Ukrainy]. Kyiv.

17. Ohinskyi, А. (2000). Загальна характеристика еволюції систем сільського господарства на території України [Zahalna 
kharakterystyka evolyutsii system silskoho hospodarstva na terytorii Ukrainy]. Ekonomika Ukrainy, 11, 55-62.

18. Order of the Ministry of Agrarian Policy of Ukraine, Ministry of Finance of Ukraine "Methodological Recommendations on the Optimal Ratio of Agricultural Crops in the Crop Rotation of Various Soil and Climate Zones of Ukraine" dated July 18, 2008 No. 440/71. Retrieved from http:// www.uazakon.com/documents/ date_cp/pg_gbcgsg/index.htm

19. Petr Sklenicka (2016). Classification of farmland ownership fragmentation as a cause of land degradation: A review on typology, consequences, and remedies. Land Use Policy, 57, 694-701. https://doi.org/10.1016/j.landusepol.2016.06.032

20. Petr Sklenicka, Vratislava Janovska, Miroslav Salek, Josef Vlasak, Kristina Molnarova (2014). The Farmland Rental Paradox: Extreme land ownership fragmentation as a new form of land degradation. Land Use Policy, 38, 587-593. https://doi.org/10.1016/j. landusepol.2014.01.006

21. Popova, O. L. (2000). Екологоекономічні проблеми сталого природокористування в аграрній сфері [Ekolohoekonomichni problemy staloho pryrodokorystuvannia $\mathrm{v}$ ahrarniy sferi]. Ekonomika APK, 11, 57-63.

22. Resolution of the Cabinet of Ministers of Ukraine "Strategy for Improving the Management Mechanism in the Use and Protection of State-Owned Agricultural Lands" dated June 07, 2017 No. 413. Retrieved from http://zakon2.rada.gov.ua/laws/show/4132017-\%D0\%BF?test=kqnMfw. ACKOimlgQZisQ0Wh5HI43Es80msh8Ie6

23. Rudenko, M. D. (1998). Енергія прогресу: Нариси з фозичної економіï [Enerhiia prohresu: Narysy z fizychnoi ekonomii] (528 p). K.: Molod'.

24. Shulha, M. V. (2015). Сучасні тенденції розвитку національного законодавства України [Suchasni tendentsii rozvytku natsionalnoho zakonodavstva Ukrainy]. Proceedings from Міжнародна науковопрактична конференція присвячена 10-річчю юридичного факультету [Mizhnarodna naukovo-praktychna konferentsiia prysviachena 10-richchiu yurydychnoho fakultetu]. Kyiv.

25. Supreme Council of Ukraine (2003). The Law of Ukraine "On
Land Protection" dated June 19, 2003 No. 962-IV. Retrieved from http://zakon5.rada.gov.ua/laws/ show/962-15

26. The Law of Ukraine "On Ratification of the Association Agreement between Ukraine, of the one part, and the European Union, the European Atomic Energy Community and their Member States, of the other part" dated June 27, 2014 No. 1678-VII. Retrieved from http://zakon3. rada.gov.ua/laws/show/1678-18

27. The Law of Ukraine "On the Main Principles (Strategy) of the State Environmental Policy of Ukraine for the period up to 2020" dated December 21, 2010 No. 2818-VI. Retrieved from http://zakon3.rada.gov.ua/laws/ show/2818-17

28. United Nations (1992). The Rio Declaration on Environment and Development dated June 14, 1992. Retrieved from http://www. un.org/ru/documents/decl_conv/ declarations/riodecl.shtml

29. Vasyl'yeva, M. I. (1999). Проблемы защиты общественного интереса в экологическом праве [Problemy zashchity obshchestvennogo interesa $\mathrm{v}$ ekologicheskom prave]. Gosudarstvo i pravo, 8, 49-62. 